\title{
Prevalence and Possibility of Management of Grapevine Root-rot in Minia Governorate, Egypt
}

\author{
Shehata, A.M.; Hussein, N.A.; Abdou, EL-S. and \\ Galal, A.A. \\ Plant Pathology Department, Faculty of Agriculture, Minia \\ University, Minia, Egypt.
}

\begin{abstract}
Crapevine root rot prevalence, incidence and severity were varied $\checkmark$ with plant age and grape variety. Young vineyards (1-3 years old) provided the highest values of prevalence, incidence and severity at Minia governorate, Egypt. Roomy grapevine variety recorded prevalence; incidence and severity values for root rot higher than Superior grapevine variety. Isolates of Fusarium sp. were the most frequent fungi associated with rotted grape roots followed by Rhizoctonia solani isolates, while other fungi, viz. Alternaria sp. Aspergillus sp. Penicillium sp. Diplodia sp. and Nigrospora sp. were the least frequent. Among 10 fungal isolates tested, Fusarium sp isolate G5 was the most infective followed by $R$. solani isolate G3 and Fusarium sp isolate G1. Identification of the most pathogenic isolates was confirmed as $F$. solani isolates $\mathrm{G} 1$ and G5 and $R$. solani isolate G3 that were used further.

Varietal response to root rotting fungi was varied with grapevine varieties and fungal isolates. Black desert grapevine variety exhibited resistance against $F$. solani and $R$. solani infection. Two grapevine varieties, Flame seedless and Early sweet reacted as moderately infected. The most susceptible variety was Superior followed by Roomy. A beneficial effect for potassium silicate against fungal growth and root rot infection was pronounced at $2 \mathrm{mM}$.
\end{abstract}

Keywords: Grapevine, Vitis vinifera, Root-rot, Fusarium solani, Rhizoctonia solani and potassium silicate.

Grapevine (Vitis vinifera L.) is the most widely distributed fruit crop in the world. About 25 million feddan are cultivated at temperate to tropical regions for direct eating fresh, food industries for multi-use and medical purposes. In Egypt, grapes are situated in the second position, preceded only by citrus crops. Because of its high net return, its cultivated area increased rapidly and the fruiting area estimated by 1,686,706 hectar, produced 168, 670, 6 tons. Minia governorate occupied the second position after Behera governorate in grapevine cultivations and production with fruiting area of 24,085 feddan with total production of more than 211,719 tons of fruits, i.e. about 8.790ton/Feddan (Anonymous, 2015).

Foliar and root-rot diseases that attack grapevine have been studied for more than 170years till now world-wide including Egypt (Pearson and Goheen, 1994; Agrios, 2005; Diez et al., 2008; Eichmann and Huckelhoven, 2008; and Hassan and Galal, 
2012). Root-rot diseases of grape vine are continuing problems for growers worldwide and are common and destructive diseases in both nursery and field. Rootrot of grape vine caused by a wide range of pathogens, Pythium ultimum in Canada (Utkhede, 1992), Phytophthora spp. in Italy (Ciccarese et al., 1992), in Mexico (Ramirez, 1994), and in Australia Rhizoctonia solani (Walker, 1994), and in Chile, (Latorre et al., 1997). Grapevine root rots observed in New Zealand included black foot rot (caused by Cylindrocarpon spp.), Verticillium wilt (caused by Verticillium dahlia), Phytophthora root-rot (caused by various Phytophthora spp.) and Armillaria root rot (caused by Armillaria novae-zelandiae and A. limonea). In Egypt, root rot of grape vine caused by Fusarium spp., Macrophomina phaseolina, Rhizoctonia solani, Pythium ultimum and Botryiodiplodia theobromae particularly in Gharbeia, and Behera governorates (Badaway, 1973; Mourad, 1983; Ziedan, 2003; Ziedan et al., 2005 and Ziedan and EL-Mohamedy, 2008). Grapevine root diseases can cause whole plant loss in vineyards, resulting in additional costs of replacement vines and the management of mixed-age plantings (Jaspers, 2013).

The present study was planned to: 1) survey grapevine root rot in different vineyards of Minia governorate, 2) isolate and identify the microorganisms associated with rotted grapevine roots and calculating their frequencies, 3) run the pathogenicity of the most frequent fungi and 4) conduct management trials.

\section{Materials and Methods}

\section{1-Field surveys and fungal isolation:}

To assess the severity and distribution of grapevine root rot of 3 various ages viz; 1-3, 4-10 and older than 10 years old, vineyards were surveyed throughout grape growing regions of all districts belong to Minia governorate, Egypt, Abo-Qurqas, Beni-Mazar, Deir-Mawas, El-Edwa, El-Minia, Maghagha, Mallawi, Mattay, Samalott, during 2016. At least 2 vineyards per plant age/district were surveyed. Five sampling sites were designated per vineyards ( 20 plants/site), one sample site from each corner and one at the center of each vineyard. Samples from the corners were at least five meters away from the edges (Úrbez-Torres et al., 2014). 2003)

The disease incidence and severity for each sampling site were assessed (Ziedan,

2-Disease assessment:

Prevalence percentage of grapevine root rot (RRP) was monitored by using the following equation:

$$
\text { Prevalence } \%=(\text { NIV/TNVV }) \times 100
$$

Where NIV=number of infected vineyards, TNVV=total number of visited vineyards. 
Root-rot disease incidence percentage (RRI) and disease severity (RRS) after 4 months from the formation of first leaf on plants were assessed (Ziedan, 2003) on shoot system as follows: $0=$ healthy, $1=$ yellowish $+1 / 3$ plant wilted, $2=2 / 3$ plant wilted, $3=$ whole plant wilted and $4=$ plants dead showed severe wilt.

$$
\text { Disease incidence }=\frac{\text { No of inf. plants }}{\text { Total of plants }} \times 100
$$

Disease severity was determined to the following equation:

$$
\mathrm{DSI}=\frac{\Sigma \mathrm{D}}{\mathrm{D} \max \times \mathrm{n}} \times 100
$$

Where $\mathrm{D}$ is the disease index on each plant, $\mathrm{d}$ max is the maximum disease index possible and $\mathrm{n}$ is the total number of plants examined in each replicate.

3- Isolation of associated fungi with rotted grapevine roots:

Different samples representing grape rotted roots were collected from only young plant, 1-3 years old of two varieties Roomy and Superior from different regions at Minia governorate. One hundred pieces of infected tissues of roots were first surface sterilized by submerging them in $0.5 \%$ sodium hypochlorite for 5 min and washed twice with sterile distilled water. After air-drying, sampled roots were inspected for presence of discolored or die back root (Walker, 1992). Fungi from roots were isolated as stated by Petit and Gubler, (2005). Small pieces (5mm) of symptomatic root tissues were incubated on potato dextrose agar (PDA) in plates at $20^{\circ} \mathrm{C}$, for 5 to 7 days until fungal colonies were observed. Fungal colonies were individually transferred to fresh PDA. After wards, pure cultures were obtained by hypha tipping from colony margins and by placing them again on fresh PDA plates and incubated at $20^{\circ} \mathrm{C}$.

4- Identification and frequency of microorganisms associated fungi with rotted grapevine roots:

Pure culture colonies were used to conduct a preliminary morphological identification of the different fungi isolated from symptomatic grapevine root tissues. The established fungal isolates were identified on the basis of culture morphology and microscopic characteristics according to Gilman, (1957); Barnett and Hunter, (1972); Nelson et al. (1983); Booth (1995) and frequency of fungi associated with rotted roots was detected as percentage.

\section{5-Pathogenicity tests:}

Unless otherwise stated, grapevine cuttings used throughout this study were taken from healthy apparent shoots for the previous growing season, uniformed length, thick and number of buds ( 5 buds/ each). Cuttings were upside down embedded in a moist soil for 40 days before planting. After that, cuttings with 2 buds were planted sub ground and those of transplanted 3 buds were up ground.

Ten fungal isolates were selected from the most frequent, i.e. Fusarium isolates; G1, G5, G6, G9 and G10, Rhizoctonia isolates; G3, G7 and G8, Alternaria isolate; 
G2 and Aspergillus isolate; G4. The selected isolates were tested for their pathogenicity to grapevine Superior variety. The pot experiment was carried out at Plant Pathology Department, Faculty of Agriculture, Minia University, Egypt. Fungal inocula were prepared on sterilized sand barely medium (60 gm barley grains, $40 \mathrm{gm}$ water washed sand and $50 \mathrm{ml}$ distilled water). The inoculated media were left for 20 days at $25 \pm 1^{\circ} \mathrm{C}$. Plastic pots $25 \mathrm{~cm}$-diameter containing sterilized soil were singly infested with each fungal inoculum at the rate of $2.5 \%(\mathrm{w} / \mathrm{w})$. Five pots were used as replicate and 3 replicates for each isolate. Two grapevine cuttings of variety, Superior were planted in each pot (30 cuttings per treatment). All agriculture practices were conducted similarly as recommended to Ministry of Agriculture, Egypt: Either RRI and RRS caused by each tested isolate were recorded, four months after planting. Re-isolation was carried out from the artificially diseased plants to fulfill Koch's postulations and the developed fungi were confirmed with the original isolates.

The most frequent and virulent isolates (2 Fusarium isolates G1 and G5 and one Rhizoctonia isolate G3) were further verified at Assiut University Mycological Center (AUMC) under code No. (13886 G1) and code No. (13888 G5) that was confirmed Fusarium solani while isolate code NO. (13887 G3) was Rhizoctonia solani.

6-Varietal response:

The response of 5 grapevine varieties; Black Desert, Early Sweet, Flame seedless, Roomy and Superior, were tested against the most virulent isolates of Fusarium solani (G1 and G5) and Rhizoctonia solani (G3). The experiment was conducted in pots during 2018 season. Inocula, inoculation, disease incidence and disease severity were conducted as described before.

7-Effect of potassium silicate on grapevine root-rot infection:

Pot experiment was carried out during 2018 season to test two concentrations of $\mathrm{K}_{2} \mathrm{SiO}_{3}(1.0 \mathrm{mM}$ and $2.0 \mathrm{mM})$ on the incidence of grapevine root rot. Soil infestation by the individual tested fungal isolates, $F$. solani G1 and G5, and $R$. solani G3 and planting Superior grapevine cuttings were essentially conducted similarly as described under pathogenicity tests. One month later, pots of inoculated or noninoculated cuttings were received the tested solution of $\mathrm{K}_{2} \mathrm{SiO}_{3}(0.0,1.0$ and $2.0 \mathrm{mM}$ concentrations singly). Three months after treatment RRI and RRS were estimated as described before.

8-Statistical analysis:

Statistical analyses of all the previously designed experiments were carried out according to (ANOVA) procedures reported by Gomez and Gomez (1994), treatment means were compared by the least significant difference test (LSD) at 5\% level of probability.

Egypt. J. Phytopathol., Vol. 47, No. 1 (2019) 


\section{Results}

1-Field survey:

During 2016 season, survey data (Table1) show various grapevine root rot prevalence (RRP), incidence (RRI) and severity (RRS) depending on viticulture grapevine varieties and plant age. Grapevine Roomy variety Showed greater values of RRP (38.3\%), RRI (12.6\%) and RRS (8\%) as compared to grapevine Superior variety, being RRP 21.6, RRI 8.3 and RRS 4.6\%, respectively. Young plants (1-3 years old) recorded the highest values of all patho-metery characters, viz RRP 65 , RRI 23 and RRS 9\%, for Roomy var., while Superior variety gave RRP 45.8, RRI 15 , and RRS 7\%, respectively, followed by medium age plants (4-10 years old) of Roomy var, which provided RRP 32\%, RRI $10 \%$ and RRS 4\%, but in case of Superior var. these values were RRP 13.6, RRI7 and RRS 5\%. The least values of disease prevalence were pronounced by older viticulture that gave RRP $18.1 \%$, RRI $5 \%$ and RRS 3\%, in case of Roomy var. but in Superior var. these values were $7 \%$ for RRP, 3\% for RRI and 2\% for RRS on the average, respectively.

Table (1): Prevalence, disease incidence and disease severity of grapevine root rot in three different plant ages of two grapevine varieties (Superior and Roomy), grown in Minia governorate during 2016.

\begin{tabular}{ccccccc}
\hline $\begin{array}{c}\text { Plant age } \\
\text { (years) }\end{array}$ & Varieties & $\begin{array}{c}\text { No. of } \\
\text { inspected } \\
\text { vineyards }\end{array}$ & $\begin{array}{c}\text { No. of } \\
\text { Infected } \\
\text { vineyards }\end{array}$ & $\begin{array}{c}\text { Prevalence } \\
\text { of root rot } \\
\%\end{array}$ & $\begin{array}{c}\text { Root rot } \\
\text { incidence } \\
\%\end{array}$ & $\begin{array}{c}\text { Root rot } \\
\text { severity } \%\end{array}$ \\
\hline $\begin{array}{c}\text { Young } \\
(1-3)\end{array}$ & Roomy & 23 & 15 & 65.2 & 23 & 9 \\
\cline { 2 - 7 } & Superior & 24 & 11 & 45.8 & 15 & 7 \\
\hline $\begin{array}{c}\text { Medium } \\
(4-10)\end{array}$ & Roomy & 25 & 8 & 32.0 & 10 & 4 \\
\cline { 2 - 7 } & Superior & 22 & 3 & 13.6 & 7 & 5 \\
\hline \multirow{2}{*}{$\begin{array}{c}\text { Old } \\
(>10)\end{array}$} & Roomy & 22 & 4 & 18.1 & 5 & 3 \\
\cline { 2 - 7 } Average & Superior & 28 & 2 & 7.3 & 3 & 2 \\
\cline { 2 - 7 } & Roomy & 23.3 & 9 & 38.3 & 12.6 & 8 \\
\hline \multirow{2}{*}{ Superior } & 24.6 & 5.3 & 21.6 & 8.3 & 4.6 \\
\hline
\end{tabular}

2-Frequency of fungi associated with rotted grapevine roots:

Seven fungal species, i.e. Alternaria sp, Aspergillus sp, Penicillium sp, Diplodia sp, Fusarium sp, Nigrospora sp and Rhizoctonia solani, were found to be associated with rotted grapevine roots of Roomy and Superior verities. Frequency of identified fungi associated with rotted grapevine roots (Table 2) indicate that Fusarium solani isolates were the most dominant $(51.1 \%)$ followed by Rhizoctonia solani $(24 \%)$ while other fungi, viz Alternaria sp, Aspergillus sp, Penicillium sp, Diplodia seriata, and Nigrospora sp, gave low frequency, being 3.5, 6.0, 4.5, 5.0 and $5.5 \%$, respectively. Frequency of fungi associated with rotted grapevine Roomy var. roots was merely to Superior grapevine variety. 
Table (2): Frequency of identified fungi associated with rotted roots of grapevine Roomy and Superior varieties grown under Minia conditions during 2016.

\begin{tabular}{lccc}
\hline \multirow{2}{*}{ Fungi } & \multicolumn{2}{c}{ Frequency to the grapevine varieties \% } & \multirow{2}{*}{ Mean } \\
\cline { 2 - 3 } & Superior & Roomy & \\
\hline Alternaria sp. & 4 & 3 & 3.5 \\
Aspergillus sp. & 5 & 7 & 6.0 \\
Penicillium sp. & 5 & 4 & 4.5 \\
Diplodia sp. & 6 & 4 & 5.0 \\
Fusarium solani & 53 & 50 & 51.5 \\
Nigrospora sp. & 5 & 6 & 5.5 \\
Rhizoctonia solani & 22 & 26 & 24.0 \\
\hline Total & 100 & 100 & 100 \\
\hline
\end{tabular}

3- Pathogenicity tests:

Ten fungal isolates were tested for their capabilities to induce root rot to grapevine Superior variety (Table 3). Fusarium solani isolate G5 exhibited the highest $86.7 \%$ RRI and 45\% RRS followed by Rhizoctonia solani isolate G3 that incited $66.7 \%$ RRI and 38\% RRS and Fusarium solani isolate G1 that caused $43.3 \%$ RRI and $28.9 \%$ RRS. Other $F$. solani and $R$. solani isolates caused moderate RRI and RRS, being 29.6 - 40.4\% RRI and 16.5 - 26.6\% RRS. Alternaria sp. isolate G2 and Aspergillus sp. isolate G4 were weakly reacted to cause root rot, less than $5.0 \%$ RRI and RRS.

Table (3): Root rot incidence (RRI) and root rot severity (RRS) of grapevine variety Superior caused by artificial inoculation with most frequent fungi.

\begin{tabular}{lcc}
\hline \multirow{2}{*}{ Fungal Isolates } & \multicolumn{2}{c}{ Pathogenicity test expressed as } \\
\cline { 2 - 3 } & Disease Incidence \% & Disease Severity \% \\
\hline Alternaria sp G2 & 3.3 & 2.2 \\
Aspergillus niger $\mathrm{G} 4$ & 3.9 & 2.5 \\
Fusarium solani $\mathrm{G} 1$ & 43.3 & 28.91 \\
Fusarium solani $\mathrm{G} 5$ & 86.7 & 45.0 \\
Fusarium solani G6 & 38 & 24.5 \\
Fusarium solani $\mathrm{G} 9$ & 35.4 & 26.6 \\
Fusarium solani $\mathrm{G} 10$ & 29.6 & 16.5 \\
Rhizoctonia solani $\mathrm{G} 3$ & 66.4 & 38.0 \\
Rhizoctonia solani G7 & 38.8 & 24.7 \\
Rhizoctonia solani G8 & 40.4 & 21.3 \\
Control & 0 & 0 \\
\hline L.S.D.at $0.05=$ & 12.83 & 6.4 \\
\hline
\end{tabular}

Egypt. J. Phytopathol., Vol. 47, No. 1 (2019) 


\section{4- Varietal response:}

Data summarized in Table (4) show significant variance of grapevine variety to infection by the tested fungi. Superior grapevine variety expressed the most susceptible, as RRI was $50.9 \%$ and RRS was $30.7 \%$, followed by Roomy variety (23.5\% and 14.9, RRI and RRS, respectively) Early sweet (17.8\% RRI), Flame seedless RRI (16.8\%), whereas Black desert grapevine variety exhibited the least mortal plants (11.9\% and 8.2 for RRI and RRS, respectively). Fusarium solani isolate G5 incited the highest mortality to all grapevine varieties tested followed by Rhizoctonia solani isolate G3 and Fusarium solani isolate G1.

Table (4): Response of various grapevine varieties to infection by Fusarium solani isolates (G1 and G5) and Rhizoctonia solani isolate (G3).

\begin{tabular}{|c|c|c|c|c|c|c|c|c|c|c|}
\hline \multirow{3}{*}{ 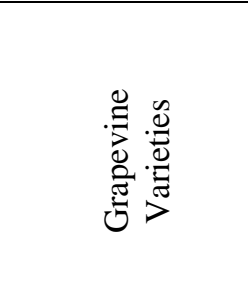 } & \multicolumn{5}{|c|}{$\begin{array}{c}\text { Root rot Incidence (RRI) } \\
\text { caused by }\end{array}$} & \multicolumn{5}{|c|}{$\begin{array}{c}\text { Root rot Severity (RRS) } \\
\text { caused by }\end{array}$} \\
\hline & ن̈ & $\begin{array}{l}\widetilde{0} \\
\vec{\Xi} \\
\overline{0} \\
0\end{array}$ & $\begin{array}{l}0 \\
\vdots \\
\vdots \\
0 \\
0 \\
0\end{array}$ & $\begin{array}{l}n \\
0 \\
0 \\
0 \\
0 \\
0\end{array}$ & $\sum^{\Xi}$ & 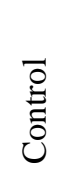 & $\begin{array}{l}\overline{0} \\
-\tilde{\Xi} \\
\frac{3}{0} \\
0\end{array}$ & $\begin{array}{l}0 \\
0 \\
0 \\
0 \\
0 \\
0\end{array}$ & $\begin{array}{l}n \\
0 \\
-3 \\
0 \\
0 \\
0\end{array}$ & $\sum_{\Sigma}^{\Xi}$ \\
\hline & & 迋 & 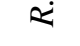 & 这 & & & 这 & $\approx$ & 这 & \\
\hline Black Desert & 0 & 11.7 & 13.2 & 22.8 & 11.9 & 0.0 & 9.0 & 6.7 & 17.3 & 8.2 \\
\hline Early Sweet & 0 & 22.2 & 26.4 & 22.6 & 17.8 & 0.0 & 13.3 & 23.4 & 16.7 & 13.3 \\
\hline Flame seedless & 0 & 16.2 & 26.3 & 24.9 & 16.8 & 0.0 & 6.7 & 18.5 & 20.1 & 11.3 \\
\hline Roomy & 0 & 25.2 & 32.2 & 36.7 & 23.5 & 0.0 & 10.0 & 26.6 & 23.3 & 14.9 \\
\hline Superior & 0 & 44.4 & 75.6 & 83.9 & 50.9 & 0.0 & 36.7 & 38 & 48.3 & 30.7 \\
\hline Mean & 0 & 23.9 & 34.7 & 38.1 & 24.1 & 0.0 & 15.1 & 22.5 & 25.1 & 15.6 \\
\hline \multicolumn{11}{|l|}{ L.S.D.at0.05 for: } \\
\hline Fungi $(A)=$ & \multicolumn{5}{|c|}{2.8} & \multicolumn{5}{|c|}{2.52} \\
\hline Varieties $(\mathrm{B})=$ & \multicolumn{5}{|c|}{2.12} & \multicolumn{5}{|c|}{1.89} \\
\hline $\mathrm{A} \times \mathrm{B}=$ & \multicolumn{5}{|c|}{8.48} & \multicolumn{5}{|c|}{7.55} \\
\hline
\end{tabular}

5- Effect of potassium silicate on grapevine root rot infection:

Potassium silicate amendment to soil at $0.2 \mathrm{mM}$ significantly reduced grapevine root rot (Table 5). Using $2.0 \mathrm{mM}$ potassium silicate caused the highest reduction in the values of RRI and RRS. The highest protection was explored by $2 \mathrm{Mm}$ potassium silicate against $F$. solani isolate G5 (40.3\%) followed by isolate G3 of $R$. solani $(31.1 \%)$ and $F$. solani isolate G1 (27.2\%), respectively. 
Table (5): Effect of soil application with potassium silicate on root rot incidence and root rot severity in grapevine Superior variety grown in infested soil by the tested fungi.

\begin{tabular}{|c|c|c|c|c|c|c|c|c|c|}
\hline \multirow[b]{2}{*}{ Fungi } & \multicolumn{4}{|c|}{ Disease Incidence } & \multicolumn{4}{|c|}{ Disease Severity } & \multirow{2}{*}{$\begin{array}{l}\stackrel{0}{0} \\
\stackrel{0}{0} \\
0 \\
0\end{array}$} \\
\hline & 0.0 & $\sum_{\Xi}$ & $\sum_{\text {¿ }}^{\lessgtr}$ & $\stackrel{\Xi}{\stackrel{\Xi}{\Sigma}}$ & 0.0 & $\sum_{\Xi}$ & 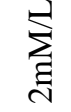 & 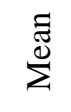 & \\
\hline F. solani G1 & 40.5 & 26 & 20 & 28.8 & 25 & 17.5 & 12.3 & 18.2 & 27.2 \\
\hline R. solani G3 & 55 & 22.3 & 18.2 & 31.8 & 30.2 & 18.9 & 13.5 & 20.8 & 31.1 \\
\hline F. solani G5 & 83.3 & 33.3 & 23.3 & 46.8 & 55 & 27.8 & 15.8 & 32.8 & 40.3 \\
\hline Control & 0.0 & 0.0 & 0.0 & 0.0 & 0.0 & 0.0 & 0.0 & 0.0 & 0.0 \\
\hline Mean & 59.6 & 27.2 & 20.5 & 35.8 & 36.7 & 21.4 & 13.8 & 23.9 & \\
\hline \multicolumn{10}{|c|}{ L.S.D.at 0.05 for: } \\
\hline \multirow{2}{*}{\multicolumn{2}{|c|}{$\begin{array}{c}\text { fungi }(\mathrm{A})= \\
\text { compounds }(\mathrm{B})=\end{array}$}} & & & 2.28 & & & & & 1.65 \\
\hline & & & & 1.71 & & & & & 1.42 \\
\hline \multicolumn{2}{|c|}{$\begin{array}{c}\text { compounds }(\mathrm{B})= \\
\mathrm{A} \times \mathrm{B}=\end{array}$} & & & 6.84 & & & & & 4.68 \\
\hline
\end{tabular}

\section{Discussion}

To achieve a successful integrated disease management program for any plant disease, several steps are needed. The first step began from the definition of the problematic diseases through making a survey for such diseases by monitoring their prevalence, disease incidence and severity (Abdou et al., 2001, Hassan and Galal, 2012 and Abdullah et al., 2015). The survey data indicated that areas cultivated with grapevine throughout Minia districts suffer from root rot diseases and root rot prevalence was varied with grape variety and age of plants .Young plants (1-3 years old) viticulture were the most affected than medium and older ones and Roomy var. grapes was the most affected than Superior var. As for root rot incidence and root rot severity, a survey, results of survey revealed the highest root rot incidence and root rot severity values were associated with young grape plants (1-3 years old vineyards) while, older plants showed lowest values. Due to the available literature, this study is the first report concerning Minia governorate, however, Hassan and Galal (2012) surveyed foliar and root rot diseases affecting vineyards growing in Minia governorate.

For integration survey studies, frequency of microorganisms associated with rotted grape roots was subsequently conducted. Seven fungal species, i.e. Alternaria sp, Aspergillus sp, Penicillium sp, Diplodia sp, Fusarium sp, Nigrospora sp and Rhizoctonia solani, were found to be associated with rotted grapevine roots of Roomy and Superior verities. The present study provided that Fusarium solani isolates showed the highest frequency $(51.15 \%)$ followed by Rhizoctonia solani (24\%) while other fungal species were less than $5 \%$ for each. Data indicated that the

Egypt. J. Phytopathol., Vol. 47, No. 1 (2019) 
two pathogenic fungi, Fusarium solani and Rhizoctonia solani generally were associated with rotted roots of grapes, this was in accordance with Walker (1994) and Zideanet al., 2011).

The ability of the isolated fungi to cause rot in grape roots revealed significant variation between fungal isolates tested. Isolates belong to Fusarium solani and Rhizoctonia solani showed a substantial RRI and RRS. Isolate G5 of Fusarium solani provided the highest RRI and RRS followed by isolate G3 Rhizoctonia solani and G1 of $F$. solani. Other $F$. solani and $R$. solani isolates expressed moderate infection effects. Otherwise, Alternaria sp. and Aspergillus sp. isolates tested reacted as weak pathogens that caused the lowest RRI and RRS which were not more than $5.0 \%$. Data showed that virulence of fungal isolates varied according to the variety tested and its age (Henis, 1970; Bumbieris, 1972 and Walker, 1992).

Identification of the most pathogenic 3 isolates was confirmed as $F$. solani isolates (G1 and G5) and R. solani (isolate G3). Thus these pathogenic isolates were only used further. Fusarium solani was reported as rot causal fungus to grape root (Zidean, 2005 and Zidean and EL-Mohamedy, 2008). The same assume was assured with R. solani (Walker, 1992; Walker, 1994 and Sandres et al., 1978). The present work explored that response of grapevine plants to root rot pathogens was significantly varied with isolates of fungi and varieties of grapevine tested. It's very important to choose cultivars with multiple pathogen resistance whenever possible, practical control of many diseases of plants (Fusarium wilt, Verticillium wilt, and gray leaf spot for tomato). Superior grapevine variety reacted as the most susceptible variety to all pathogenic isolates tested followed by Roomy variety, whereas Black Desert grapevine variety reacted as a resistant variety to all tested root rotting isolates, However, such resistant variety could be recommended to use as rootstock Flame and Early sweet were moderately infected. Data indicated that virulence of root rotting fungi varied depending on varietal response These results are in agreements with those reported by several investigators (Baumgartner and Rizzo, 2001; Baumgartner and Rizzo, 2002 and Baumgartner and Rizzo, 2006).

Silicon ( $\mathrm{Si}$ ) is a bioactive element associated with beneficial effects on mechanical and physiological properties of plants. Several studies have suggested that $\mathrm{Si}$ activates plant defense mechanisms, yet the exact nature of the interaction between the element and biochemical pathways leading to resistance remains unclear. It can act as a modulator influencing the timing and extent of plant defense responses in a manner reminiscent of the role of secondary messengers in induced systemic resistance; it can also bind to hydroxyl groups of proteins strategically involved in signal transduction; or it can interfere with cationic co-factors of enzymes influencing pathogenesis-related events. (Belanger et al., 2003; Rodrigues et al., 2003; Fauteux et al., 2005 and Cruz et al., 2013). The current study expressed a beneficial effect for potassium silicate against the infectivity of grapevine root rot pathogens. Soil amendment with potassium silicate caused the highest protection (40.3\%) against $F$. solani isolate G5 followed by $R$. solani isolate G3 (31.1\%) and $F$. 
solani isolate G1 (27.2\%). Data are consistent with the effect of potassium silicate on several plant pathogens interactions (Cai et al., 2008; Dallagno et al., 2009; Epstein, 2009 and Guntzer et al., 2012).

\section{References}

Abdou, EL-S.; Abd-Alla, H.M.; and Galal, A.A. 2001. Survey of sesame root rot/wilt disease in Minia and their possible control by ascorpic and salicylic acids. Assiut J. Agricultural Sci., 32(3):135-152.

Abdullah, S.K.; AL-Samarraie, M.Q. and AL-Assie, A.H. 2015. Fungi associated with grapevine (Vitis vinifera L) decline in middle of Iraq. Egypt. Acad. J. Biol. Sci., 7(1):53-59.

Agrios, G.N. 2005. Plant Pathology. th $^{\text {th }}$ Ed., Elsevier Academic Press, Pp1451.

Anonymous, 2015. Annual Reports of Statistical Institute and Agriculture Economies Research in A.R.E. Agric. and Land Reclamation Ministry (2015).

Badaway, M.F. 1973. Studies on the decayed grape cutting in nursery in Egypt .M.Sc. Thesis Fac. Agric, AL-Azhar. Univ. Egypt, pp 180.

Barnett, H.L. and Hunter, B.B. 1972. Illustrated Genera of Imperfect Fungi.3 ${ }^{\text {rd }}$ Edition, Burgess Publishing Co., Minneapolis, Pp 1-241.

Baumgartner, K. and Rizzo, D.M. 2001. Ecology of Armillaria species in mixedhardwood forests of California. Plant Disease, 85:947-951.

Baumgartner, K. and Rizzo, D.M. 2002. Spread of Armillaria root disease in California vineyards. Am. J. Vitic., 53:197-203.

Baumgartner, K. and Rizzo, D.M. 2006. Relative resistance of grapevine rootstocks to Armillaria root disease. Am. J. Enol. Vitic., 57: 408-414.

Belanger, R.R.; Benhamou, N. and Menzies, J.G. 2003. Cytological evidence of an active role of silicon in wheat resistance to powdery mildew (Blumeria graminis fsp. tritici). Phytopathology, 93:402-412.

Booth, C., 1995. Fusarium: Laboratory Guide to the Identification of the Major Species. The Common Wealth Mycological Institute, Kew, Pp1-237.

Bumbieris, M. 1972. Observations on some pythiaceous fungi associated with grapevine decline in South Australia. Australian J. Agric. Res., 23: 651-657.

Cai, K.Z.; Gao, D.; Luo, S.M.; Zeng, R.S.; Yang, J.Y. and Zhu, X.Y. 2008. Cytological mechanisms of silicon-induced resistance in rice against blast disease. Physiol. Plant. 134: 324-333.

Ciccarese, F.; Frisullo, S. and Amenduni, M. 1992. Observations of foot rots of Actinidia in southern Italy. Informatore Fitopathologico, 42(2):57-58.

Cruz, M.F.; Rodrigues, F.A.; Diniz, A.P.C.; Moreira, M.A. and Barros, E.G. 2013. Potassium silicate and calcium silicate on the resistance of soybean to Phakopsora pachyrhizi infection. Bragantia Campinas, 4: 373-377.

Egypt. J. Phytopathol., Vol. 47, No. 1 (2019) 
Dallagnol, L.J.; Rodrigues, F.A.; Mielli, M.V.B.; Ma, J.F. and Datnoff, L.E. 2009. Defective active silicon uptake affects some components of rice resistance to brown spot. Phytopathology, 99: 116-21.

Diez, N.A.M.; Wiedemann, M.S.; Greif, C. and Merdinoglu, D. 2008. Non host versus host resistance to the grapevine downy mildew, Plasmopara viticola, studied at tissue level. Phytopathology, 98: 776-780.

Eichmann, R. and Huckelhoven, R. 2008. Accommodation of powdery mildew fungi in intact plant cells. J. Plant Physiol., 165: 5-18.

Epstein, E. 2009. Silicon its manifold roles in plants. Ann. Appl.Biol., 155: 155-160.

Fauteux, F.; Remus-Borel, W.; Menzies, J.G. and Belanger, R.R. 2005. Silicon and plant disease resistance against pathogenic fungi. FEMS Microbiology letters, 249:1-6.

Gilman, J.C. 1957. A Manual of Soil Fungi ( $2^{\text {nd }}$ ed.) The Iowa State Univ. Press. Ames, Iowa, Pp1-450.

Gomez, K.A. and Gomez, A.A. 1994. Statistical Procedures in Agricultural Research, by New York, Chichester, etc.: Willy, $2^{\text {nd }}$ ed., Paperback, PP. 1-680.

Guntzer, F.; Keller, C. and Meunier, J.D. 2012. Benefits of plant silicon for crops, Agron. Sustain. Dev., 32: 201-213.

Hassan, H.M.M. and Galal A.A. 2012. Diseases affecting foliars and fruits of grapevine under filed conditions of Minia governorate. Minia J. Agric. Res. \& Develop., 32(1): 65-82.

Henis, Y. 1970. Significance of population level of Rhizoctonia solani in soil. In Root Diseases and Soil Borne Pathogens. (EdsT. A. Toussoun, R.V. Bega and P.E. Nelson), pp.34-36.

Jaspers, M.V. 2013. Black foot in vineyards. New Zealand Wine growers Fact Sheet N ZTD 102. http://www.nzwine.com/assets/sm/upload/zp/51/nm/g8/NZTD10.

Latorre, B.A.; Wicox, W.F. and Banados, M.P. 1997. Crown and root-rot of table grapes caused by Phytophthora spp. in Chile. Vitis., 36 :195-197.

Mourad, M.Y. 1983. Studies on root-rot disease of grape in Egypt and its control. Ph.D. Thesis, Fac. Agric., Cairo Univ., Egypt, Pp162.

Nelson, P.E.; Toussun, T.A. and Marasas, W.F.O. 1983. Fusarium spp. An Illustrated Manual for Identification. Univ. Park: The Pennsylvania State Univ. Press. Pp 1-189.

Pearson, C.R. and Goheen, A.C. 1994. Compendium of grape diseases. APS Press. Pp94.

Petit, E. and Gubler, W.D. 2005. Characterization of Cylindrocarpon species, the cause of black foot disease of grapevines in California. Plant Disease, 89: 1051-1059. 
Ramirez, J.A. 1994. Diseases caused by fungi on fruit trees in the Hermosillo Coast, Mexico. Revista-Mexicana-disease Fitopatologia, 12: 183-188.

Rodrigues, F.A.; Benhamou, N.; Datnoff, L.E.; Jones, J.B. and Belanger, R.R. 2003. Ultrastructural and cytochemical aspects of silicon-mediated rice blast resistance. Phytopathology, 93: 535-546.

Sanders, P.L.; Burpee, L.L. and Cole, H. 1978. Preliminary studies on binucleate turf grass pathogens that resemble Rhizoctonia solani. Phytopathology, 68: 145148.

Úrbez-Torres, J.R.; Haag, P.; Bowen, P. and O'Gorman, D.T. 2014. Grapevine trunk diseases in British Columbia: Incidence and characterization of the fungal pathogens associated with black foot disease of grapevine. Plant Disease, 98: 456-468.

Utkhede, R.S. 1992. Biological control of soil-borne pathogenic of fruit trees and grapevines. Can. J. Plant Pathol., 14(1): 100-105.

Walker, G.E. 1992. Root rot of grapevine root lings in South Australia caused by Rhizoctonia solani. South Australian Department of Agriculture, Loxton, South Australia 5333. Australasian Plant Pathology, 21: 58-60.

Walker, G.E.; 1994. Growth of grapevine rootling in soil from a field nursery naturally infested with Meloidogyne incognita and Rhizoctonia solani. South African J. Ecology and Viticulture, 15(2): 26-32.

Ziedan, E.H.; Embaby, E.M. and Farrag, E.S. 2011. First record of Fusarium vascular wilt on grapevine in Egypt. Archives of Phytopathology and Plant Protection, 44: 1719-1727.

Ziedan, E.H. 2003. Root-rot diseases of grapevinein Egypt. J. Agric. Sci. Mansoura Univ., 28(2): 147-1481.

Ziedan, E.H. and EL-Mohamedy, R.S. 2008. Application of Pseudomonas fluorescens for controlling root-rot disease of grapevine. Res. J. Agric. and Biol. Sci., 4(5): 346-353.

Ziedan, E.H.; Saad, M.M. and Farrag E.S., 2005. Biological control of grapevine root-rot by antagonistic microorganisms. African Mycology and Biotech., 13(3): 19-36.

Corresponding author: Galal, A.A.

E-mail: anwar_galal@yahoo.com

(Received 07/04/2019;

in revised form 21/04/2019)

Egypt. J. Phytopathol., Vol. 47, No. 1 (2019) 


\section{تواجد وإمكانية مكافحة أمراض عفن جذور العنب

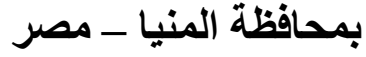

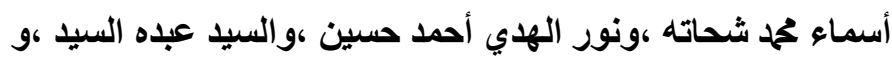 انور عبد العزيز جلال ماند} قسم أمراض النبات ، كلية الزراعة ، جامعة المنيا ، المنيا ، مصر

إختلفت نسب تواجد أمراض عفن جذور العنب في محافظة المنيا -

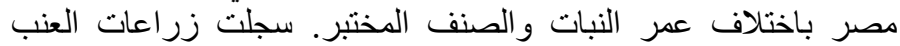

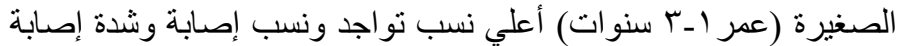

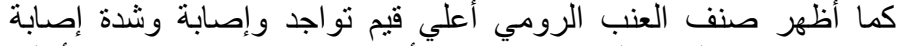

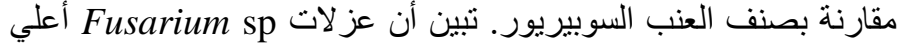

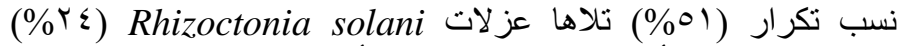
Alternaria sp, وتوجد عزلات أخري تابعة لخمس أجناس لات Aspergillus sp, Penicillium sp, Diplodia sp and

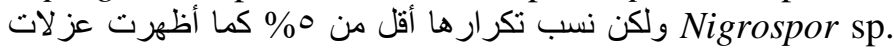

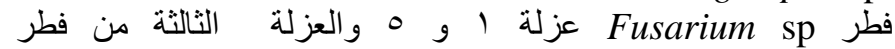
Rhizoctonia solani

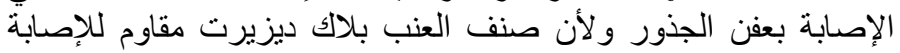

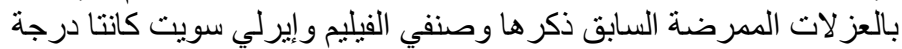

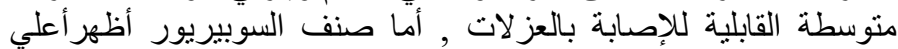

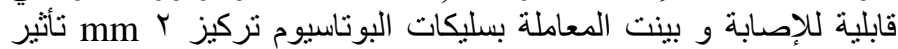

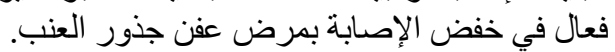

